\title{
IMPLEMENTATION OF ISTISHNA AND SALAM CONTRACT TO SONGKO RECCA CRAFTS Muhammad Wahyuddin Abdullah ${ }^{1}$, Nurul Faqiha ${ }^{2}$ Fakultas Ekonomi dan Bisnis Islam UIN Alauddin Makassar Jl. HM Yasin Limpo No.36, Samata-Gowa. e-mail: tosir_wahyu@yahoo.com, Nurulfaqiha90@gmail.com
}

\begin{abstract}
ABSTRAK
Penelitian ini bertujuan untuk mengetahui penerapan nilai-nilai ekonomi Islam dalam transaksi akad istishna dan akad salam pada perajin songko recca. Fokus penelitian ini hanya berfokus pada nilai ekonomi Islam antara perajin dan pembeli songko recca. Penelitian ini menggunakan paradigma penelitian kualitatif dengan pendekatan fenomenologi. Peneliti mengambil data dengan melakukan observasi, teknik wawancara dan dokumentasi. Data sekunder didapatkan dari literatur review yang diperoleh dari buku, penelitian terdahulu serta website yang memberikan informasi tentang nilai-nilai perekonomian Islam. Adapun metode analisis data menggunakan teknik reduksi data, penyajian data, penarikan kesimpulan. Hasil penelitian ini menunjukkan sebagian besar dari perajin telah menerapkan nilai-nilai ekonomi Islam ini. Hal ini ditunjukkan dimulai pada saat akad atau proses pemesanan dilakukan hingga proses barang selesai dan siap dikirimkan. Nilai keadilan serta nilai kejujuran yang diterapkan oleh sebagian besar perajin memberikan dampak positif bagi usaha mereka. Selain itu akan memunculkan nilai tambah bagi perajin.
\end{abstract}

Kata Kunci: Nilai; Salam; Istishna; Songko Recca.

\section{ABSTRACT}

This study aims to determine the application of Islamic economic values in istishna and salam contract transactions for Songko Recca artisans. This study's focus only focuses on Islam's economic value between craftsmen and buyers of Recca songkok. This study uses a qualitative research paradigm with a phenomenological approach. Researchers took data by making observations, interview techniques, and documentation. Secondary data is obtained from literature reviews received from books, previous research, and websites that provide information about Islamic economic values. The data analysis method uses data reduction techniques, data presentation, concluding. The results of this study indicate that most of the craftsmen have applied Islamic economic values. This is shown starting at the contract or the ordering process until the goods are finished and ready to be shipped. The value of fairness and honesty applied by most craftsmen has a positive impact on their business. Besides, it will bring added value to crafters.

Keywords: Value; Regards; Istishna; Songko Recca. 


\section{PENDAHULUAN}

Sistem transaksi terdapat berbagai macam cara yang bisa dilakukan, selama transaksi tersebut tidak menyalahi nilai-nilai ekonomi Islam. Namun dalam sistem transaksi yang melakukan proses pemesanan biasanya menggunakan akad salam dan akad istishna. Akad salam ini sangat penting dilakukan oleh penjual yang melakukan sistem jual beli online. Sedangkan akad istishna dapat dilakukan pada transaksi online atau penjual beli pesanan biasa dengan sistem panjar, cicilan ataupun pembayaran di akhir sesuai dengan kesepakatan. Ekonomi Islam memiliki sifat dasar sebagai ekonomi rabbani dan insani. Disebut rabbani karena sarat dengan arahan dan nilai-nilai ilahiah. Lalu ekonomi dikatakan memiliki dasar sebagai ekonomi insan karena system ekonomi ini dilaksanakan dan ditujukan untuk kemakmuran manusia (Qardhawi:1997). Ekonomi Islam bertujuan untuk mensejahterahkan secara adil dan seimbang karena dengan landasan ini para pihak yang terlibat dalam proses ekonomi tidak akan saling menindas atau mengeksploitasi satu sama lain (Amalia 2009:357). Mengkaji nilai-nilai Islami secara menyeluruh merupakan pekerjaan yang sangat besar, karena nilai-nilai Islam tersebut menyangkut berbagai aspek dan membutuhkan telaah yang luas. Kajian nilai-nilai Islam menyangkut beberapa aspek yang dimilki oleh seorang muslim. Sebelum menanamkan nilai-nilai Islam, terlebih dahulu memahami ajaran agama Islam secara keseluruhan, yang mencakup 3 hal pokok yaitu: pertama, Islam yang meliputi rukun yaitu mengucapkan dua kalimat syahadat, mendirikan sholat, membayar zakat, berpuasa di bulan ramadhan, melaksanakan haji bagi yang mampu. Kedua, iman yang meliputi enam rukun yakni Iman kepada Allah, Iman kepada malaikat Allah, Iman kepada Kitab Allah, Iman kepada Rasul Allah, Iman kepada hari akhir, Iman kepada qadha dan qadhar. Ketiga, Ihsan yaitu beribadah kepada Allah seolah-olah kita melihat Allah dan jika tidak dapat melihat-Nya kita meyakini Allah melihat kita.

Tujuan penulisan ini adalah untuk mengetahui apakah penerapan nilainilai perekonomian Islam dalam transaksi akad salam dan istishna pada perajin songko' recca (songko to Bone)Awangpone di Kabupaten Bone berjalan sesuai dengan syariat Islam. Kegiatan membuat songko recca memiliki nilai-nilai ekonomi Islam seperti nilai transparansi sebelum memesan barang. Para perajin harus memberikan penjelasan kepada para pembeli tentang bahan yang digunakan serta kualitas bahan yang diinginkan. Hal ini dilakukan agar tidak ada pihak yang merasa dirugikan. Al-Qur'an pun telah dijelaskan bahwa harus 
ada transparansi dalam berdagang. Islam mengajarkan kepada kita ilmu berdagang yang baik, etika atau adab berdagang yang benar. Seharusnya kita sebagai orang Islam menjunjung tinggi bagaimana etika yang di ajarkan Islam dalam urusan jual beli atau berdagang. Jujur iman seseorang akan diuji melalui kejujurannya saat berdagang. Contohlah apa yang Rasulullah lakukan ketika berdagang, beliau selalu mengutamakan kejujuran. Seperti misalnya ketika beliau memberikan penjelasan tentang kualitas atau spesifikasi suatu barang, menghitung timbangan dan lain sebagainya. Allah berfirman QS. Asy Syuaraa: 181- 183.

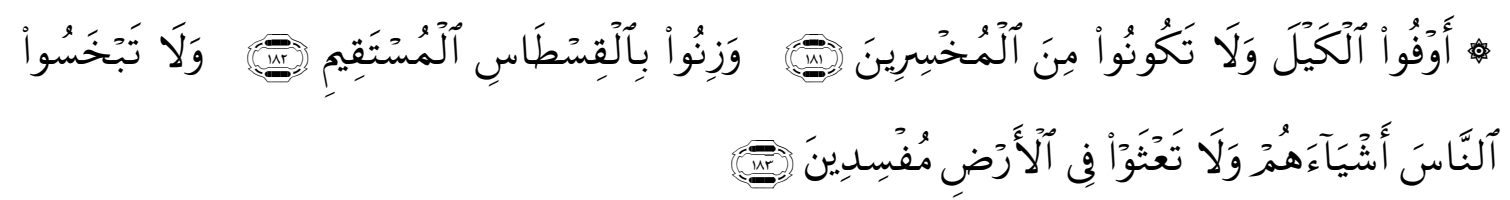

Terjemahnya:

"Sempurnakanlah takaran dan janganlah kamu termasuk orang-orang yang merugikan, dan timbanglah dengan timbangan yang lurus, dan janganlah kamu merugikan manusia pada hak-haknya dan janganlah kamu merajalela di muka bumi dengan membuat kerusakan".

\section{Perekonomian Islam}

\section{TINJAUAN TEORITIK}

Ekonomi Islam merupakan ilmu pengetahuan sosial yang mempelajari masalah-masalah ekonomi rakyat yang diilhami oleh nilai-nilai Islam. Ekonomi Islam berbeda dari kapitalisme,sosialisme, maupun negara kesejahteraan (Welfare State). Berbeda dari kapitalisme karena Islam menentang eksploitasi oleh pemilik modal terhadap buruh yang miskin, dan melarang penumpukan kekayaan.Selain itu, ekonomi dalam kaca mata Islam merupakan tuntutan kehidupan sekaligus anjuran yang memiliki dimensi ibadah yang teraplikasi dalam etika dan moral. Ekonomi Islam menetapkan bentuk perdagangan dan perkhidmatan yang boleh dan tidak boleh ditransaksikan.Ekonomi Islam harus mampu memberikan kesejahteraan bagi seluruh masyarakat, memberikan kesempatan seluas-luasnya kepada setiap pelaku usaha.Ekonomi Islam mempunyai tujuan memberikan keselarasan bagi kehidupan di dunia. Hal ini karena nilai Islam tidak hanya untuk kehidupan muslim, tetapi untuk seluruh makhluk hidup di muka bumi. 
Abdullah,: Regards; Istishna; Songko Recca.

\section{Nilai-Nilai Ekonomi Islam}

Nilai- nilai Islam pada hakikatnya adalah sekumpulan dari prinsipprinsip hidup, ajaran-ajaran tentang bagaimana manusia seharusnya menjalankan kehidupannya di dunia ini, yang satu prinsip dengan lainnya saling terkait membentuk satu kesatuan yang utuh tidak dapat dipisah-pisahkan.

Nilai ke-Islaman dapat didefinisikan sebagai konsep dan keyakinan yang dijunjung tinggi oleh manusia mengenai beberapa masalah pokok yang berhubungan dengan Islam untuk dijadikan pedoman dalam bertingkah laku, baik nilai itu bersumber dari Allah maupun hasil interaksi manusia tanpa bertentangan dengan syariat.

\section{Kejujuran/Transparansi}

Dalam bahasa arab, kata jujur sama maknanya dengan "ash-shiddiq" yang berarti nyata, benar, atau berkata benar. Lawan kata ini adalah dusta, atau dalam bahasa arab"al-kadzibu". Secara istilah, jujur atau ash-shiddiq bermakna kesesuaian antara ucapan dan perbuatan, kesesuaian antara informasi dan kenyataan, ketegasan dan kemantapan hati, serta sesuatu yang baik yang tidak dicampuri dengan kedustaan.Menurut Imam al-Ghazali ada enam tingkatan kejujuran: pertama, jujur dalam perkataan, kedua, kejujuran dalam niat hanya karena Allah, ketiga, kejujuran dalam bertekad, keempat, memenuhi tekad, kelima, kejujuran dalam beramal, keenam, kejujuran dalam maqam-maqam agama.

\section{Keadilan}

Islam adil didefinisikan sebagai "tidak menzalimi dan tidak terzalimi". Implikasi ekonomi dari nilai ini adalah bahwa pelaku ekonomi tidak dibolehkan untuk mengejar keuntungan pribadi bila hal itu merugikan orang lain atau merusak alam. Tanpa keadilan, manusia akan terkelompok-kelompok dalam berbagai golongan. Golongan yang satu akan menzalimi golongan yang lain. Keadilan ini ada dalam bukunya Ushul Fiqih, Abu Zahra berpendapat bahwa hukum Islam ditunjukkan kepada tiga perkara yakni: Tahzib al-Fard, yaitu mensucikan jiwa setiap muslim agar dapat menjadi sumber kebahagiaan bagi dirinya, masyarakat dan lingkungannya. Al-Iqamah al-Adl fi al-jama'ah alIslamiyah, yaitu menegakkan keadilan dalam bermasyarakat Islam, adil baik menyangkut urusan sesama kaum muslimin maupun dengan pihak lain (non muslim)Mashlahah, yaitu untuk memelihara kemashlahatan dan merupakan tujuan puncak yang hendak dicapai dalam setiap penetapan hukum Islam.

\section{Keberkahan}

Berkah berasal dari kata barokah (jamak: barokaat) yang menurut $M$ Quraish Shihab dalam tafsir Al-Misbah bermakna sesuatu yang mantap, 
kebijakan yang melimpah dan beraneka ragam serta bersinambungan. Segala penambahan yang tidak terukur oleh indra dinamai barokah/berkahAdanya berkah pada sesuatu berarti adanya kebajikan yang menyertai sesuatu itu. Keberkahan akan datang jika diundang melalui tiga jalan yakni, pertama keimanan kepada Allah Swt. Kedua, mencintai ulama, Ketiga, transaksi yang jujur.

\section{Transaksi Islam}

Transaksi merupakan suatu kegiatan yang dilakukan seseorang yang menimbulkan perubahan terhadap harta atau keuangan yang dimiliki baik itu bertambah ataupun berkurang.Misalnya menjual harta, membeli barang, membayar hutang, serta membayar berbagai macam biaya untuk memenuhi kebutuhan hidup.

\section{Akad istishna}

Berdasarkan Fatwa DSN-MUI No.06/DSN-MUI/IV/2000 tentang jualbeli istishna. Istishna berarti minta dibuatkan/dipesan. Akad yang mengandung tuntutan agar tukang/ahli (shani) membuatkan suatu pesanan dengan ciri-ciri khusus. Demikian istishna adalah jual beli antara pemesan dan penerima pesanan, dimana spesifikasi dan harga barang disepakati di awal sedangkan pembayaran dilakukan secara bertahap sesuai kesepakatan (Adesy : 2016:97)

\section{Akad Salam}

Berdasarkan dari Fatwa Dewan Syariah Nasional Nomor 05/DSNMUI/IV/2000 tentang jual beli salam. Salam merupakan suatu bentuk jual beli dengan pembayaran di muka dan penyerahan barang di kemudian hari (advance payment atau forward buying atau future sales) dengan harga, spesifikasi, jumlah, kualitas, tanggal dan tempat penyerahan yang jelas, serta disepakati sebelumnya dalam perjanjian (Ascarya:2015:90)

\section{Konsep UMKM (Usaha Mikro Kecil Menengah)}

UMKM adalah unit usaha produksi yang berdiri sendiri, dilakukan oleh orang perorangan atau Badan Usaha disemua sektor ekonomi. Di Indonesia, defenisi UMKM diatur berdasarkan Undang-Undang RI Nomor 20 Tahun 2008 tentang Usaha Mikro, Kecil, dan Menengah (UU No.20:2008)

\section{Songko Recca (Songko To Bone)}

Songko to Bone merupakan ciri khas songko orang bugis (kelengkapan pakaian adat orang bugis), khususnya kaum laki-laki.Songko ini juga dikenal dengan songko pamiring (pamiring=pinggir) karena pada bagian bawah songko/pinggiran bagian bawah diselingi dengan benang emas atau benang 
perak. Selain itu dikenal juga dengan namasongko to Bone. Pemberian namasongko to Bone kemungkinan disebabkan oleh karena songko ini pertama kali dibuat di Bone. Namun sekarang pembuatannya sudah ada di daerah lain seperti di Kabupaten Takalar. Songko to Bone umumnya 2 warna yaitu warna hitam dan krem dengan warna pamiring keemasan (Darwis: Kompasiana:2015)

Songko to Bone atau songko recca terbuat dari serat pelepah daun lontar dengan cara dipukul-pukul (bahasa bugis: direcca-recca) pelepah daun lontar tersebut hingga yang tersisa hanya seratnya. Serat ini biasanya berwarna putih, akan tetapi setelah dua atau tiga jam kemudian warnanya berubah menjadi kecoklatan. Untuk mengubah menjadi hitam maka serat tersebut direndam dalam lumpur selama beberapa hari. Jadi serat yang berwarna hitam itu bukanlah karena sengaja diberi pewarna sehingga menjadi hitam (Yunus:200:7)

\section{Nilai Tambah}

Nilai tambah syariah adalah nilai tambah ekonomi,dimana nilai tambah ekonomi ialah nilai tambah yang dapat diukur dengan cara moneter, sedangkan nilai mental dan spiritual tidak dapat diukur dengan cara demikian yang diperoleh, diproses, dan didistribusikan dengan cara yang halal. Nilai tambah ekonomi secara umum berupa kesejahteraan dalam bentuk uang. Sementara nilai mental dan spiritual bentuknya dapat dikembangkan sesuai dengan temuan-temuan empiris yang ada dalam masyarakat (Triyuwono:2011:197-198). Nilai tambah mental (mental value added) berupa rasa altruistik, rasa senang, dan rasa persaudaraan. Altruistik adalah sifat mementingkan orang lain dari pada dirinya sendiri. Ketika kita meninggalkan ego dan mengedepankan sifat altruistic dalam bentuk misalnya menolong orang lain, maka yang timbul adalah rasa senang. Rasa yang luar biasa berpengaruh bagi kepribadian seseorang (Triyuwono:2011:192). Rasa senang biasanya muncul karena senang menerima uang hasil jerih payah. Keceriaan tersebut menunjukkan kepuasan atas hasil yang diperoleh. Sementara nilai tambah spiritual (spiritual value added) berupa rasa ikhlas dan rasa kehadiran Tuhan (Triyuwono:2011:194)

\section{METODE PENELITIAN}

Penelitian ini menggunakan penelitian kualitatif deskriptif. Karena data yang diteliti berupa kata-kata dan bukan angka. Penelitian kualitatif adalah metode pengkajian suatu data atau suatu metode yang digunakan pada penelitian terhadap suatu masalah yang tidak menggunakan metode statistik. Metode analisis yang digunakan yakni analisis wacana. Analisis wacana 
digunakan untuk menganalisis intraksi dengan orang-orang, dimana terjadi komunikasi antara peneliti dan responden terjadi (Annisa: 2020). Pendekatan fenomenologi agar selalu fokuskan untuk menggali, memahami, dan menafsirkan arti fenomena, peristiwa, dan hubungannya dengan orang-orang biasa dalam situasi tertentu (Yusuf:2014:351). Sedangkan sumber data dalam penelitian ini data primer diproleh dan dikumpulkan langsung dengan melakukan observasi serta melakukan wawancara langsung ke pengrajin songko recca melalui tatap muka secara langsung dan data sekunder didapatkan dari literatur review yang diperoleh dari buku, penelitian-penelitian terdahulu serta website-website yang memberikan informasi tentang nilai-nilai perekonomian Islam. Teknik pengumpulan data dalam penelitian kualitatif sangat berpengaruh pada hasil penelitian nantinya oleh karena itu penelitian menggunakan teknik pengumpulan data yaitu observasi, wawancara, dan dokumentasi.

\section{HASIL PENELITIAN DAN PEMBAHASAN}

\section{Nilai-Nilai Islam dalam Transaksi Akad Istishna dan Akad Salam pada Perajin Songko Recca (Songko to Bone) Awangpone}

Proses transaksi pemesanan barang terdapat pula akad-akad yang harus dijalankan. Akad yang dilakukan pada proses transksi songko recca adalah akad salam dan istishna. Objek istishna selalu barang yang harus diproduksi, sedangkan objek salam bisa untuk barang apa saja, baik harus diproduksi lebih dahulu maupun tidak diproduksi lebih dahulu. Akad ini juga dilakukan pada transaksi jual beli songko recca. Seorang pengrajin menjelaskan tentang proses pemesanan serta pembayarannya, beliau adalah saudari Hesti.

Menurut Hesti (2018), " proses pembayaran kalau pembelinya langganan kadang pembayarannya setelah barang dikirim, pembarannya dengan sistem transfer kalau memang jaraknya jauh. Tapi kalau pembeli baru harus membayar dulu baru kami berikan barangnya, apalagi kalau songko yang di pesan itu terbuat dari bahan tembaga atau emas dengan harga yang lumayan cukup mahal. Saya tidak menerima pembayaran cicil kalau dia pembeli baru, karena belum bisa di percaya, kecuali kalau memang sudah langganan, boleh membayar cicil".

Hasil wawancara proses penjualan antara pengrajin dengan pembeli bisa dikategorikan dalam proses transaksi online. Karena proses penjualannya dengan melihat barang yang ada di foto, kemudian memesan barang, di mana proses pembayarannya pula bisa di bayar di awal ataupun di akhir. Melihat dari 
penjelasan pengrajin, bahwa pembeli yang boleh membayar di akhir hanya pembeli yang sudah dipercaya dan sudah menjadi langganan, sehingga sudah ada kepercayaan dari kedua belah pihak. Sehingga pada kasus ini pengrajin memilih untuk membayar di awal. Apalagi bila songko yang dipesanoleh pembeli adalah songko dengan kualitas dan harga yang tergolong bagus dan mahal. Syamsul Bahri juga menjelaskan proses pembayarannya:

Menurut Samsul Bahri (2018), “kalau masalah pembayarannya itu setelah barang selesai dibuat karena saya melakukan proses pemesanan, bukan membeli secara langsung, namun pernah di lain waktu pada saat saya memesan songko, perajin meminta saya untuk membayar panjar dulu supaya ada kesepakatan tanda jadi"

Pembeli juga memberikan penjelasan bahwa sahnya akad apabila kedua belah pihak saling menyepakati kesepakatan antara mereka berdua. Memberikan panjar sebagai bukti setujunya pembeli untuk membeli songko recca. Hasil wawancara peneliti dengan pembeli bahwa pembeli pernah melakukan transaski membeli songko recca dengan cara pembayaran harus di panjar agar ada tanda bukti jadi. Penjual melakukan hal ini agar dalam transaksinya pihak pembeli tidak dapat membatalkan pemesanannya saat barangnya sudah dalam proses produksi. Harga dalam akad salam harus dibayar penuh di muka, sedangkan harga dalam akad istishna tidak harus dibayar penuh di muka melainkan dapat juga dicicil atau dibayar dibelakang. Hal ini saudara Bahri telah melakukan akad istishna. Akad salam efektif tidak dapat diputuskan secara sepihak, sementara dalam istishna akad dapat diputuskan sebelum perusahaan mulai memproduksi.

Pengrajin pun menjelaskan tentang penyerahan barangnya, beliau adalah Darni dan ibu Nani. Hasil wawancara tersebut menjelaskan bahwa walaupun pengrajin telah menjanjikan waktu penyelesaiannya pada waktu yang telah di sepakati sebelumnya, namun bila terjadi sesuatu hal yang tidak dapat diduga sebelumnya, pengrajin akan menyerahakan kembali kepada pembeli, apakah pembeli ingin membatalkan pemesanan ataukah tetap ingin melanjutkan. Namun ternyata kebanyakan dari pembeli memilih untuk tetap melanjutkan pemesanannya itu. Hal itu dilakukan pembeli karena apabila pembeli membatalkan, dan memesan d tempat lain, di khawatirkan di tempat lain akan lebih lama proses pengerjaannya dan pembeli akan membutuhkan lebih banyak waktu untuk menunggu. Hasil wawancara dengan bu Nani pun menyerahkan kembali kepada pembeli, dan bila pembeli memang sudah sangat membutuhkan songko itu atau sudah mau digunakan, bu Nani akan mengusahkan untuk 
menjual songko dari orang lain, dalam artian perajin yang sudah menjadi kenalan bu Nani. Ibu Nani telah mempertahankan kepercayaan pembeli terhadap dirinya sekaligus telah membantu perajin lain karena telah menjualkan songkonya itu. Proses penyerahan barangnya pun ada beberapa yaitu dengan mengantarkan sendiri kepada pembeli, melalui kurir, ataupun pembeli yang langsung datang ke tempat perajin. Mempercayai orang lain akan membangkitkan ketenangan batin dan menjalin hubungan persaudaraan yang lebih akrab dan rukun. Penerapan nilai Islam dalam bisnis mendorong setiap pelaku bisnis untuk saling mempercayai (Adesy:2016).

Menjelaskan jenis serta kualitas songko kepada pembeli merupakan salah satu sikap jujur dari perajin. Karena sikap yang jujur akan membawa kepada usaha yang halal. Hal ini juga tercermin dari cara perajin memberikan penjelasan kepada para pembeli terkait jenis bahan dan kualitas bahan serta harga yang ditawarkan. Sehingga pembeli merasa puas saat membeli songko tersebut. pembeli juga menjelaskan hal demikian, beliau adalah Andi Astura.

Menurut Andi Astura (2018), "Pada saat saya memesan songko ini, perajin menjelaskan kepada saya jenis bahan untuk songko kualitas yang bagus. Kalau kualitas yang bagus memakai serat yang halus sedangkan kalau yang kualitas biasa-biasa memakai serat yang kasar".

Hasil wawancara peneliti dengan pembeli bahwa perajin tetap memberikan penjelasan tentang bahan yang akan digunakan untuk membuat songko. Perajin juga memberikan pilihan bahan yang akan di pesannya. Pengrajin akan menunjukkan berbagai model serta kualitas songkonya. Pada saat itulah pembeli akan merasa bahwa pengrajin ini benar-benar terbuka tentang bahan dari songkonya. Cara ini berlaku pada akad salam dan istishna. Sebelum memesan barang dan sebelum kedua mengiyakan barang tersebut, pengraji terlebih dahulu harus menjelaskan jenis bahan tersebut.

Selain itu saudara Dandi Setyadi juga menjelaskan mengenai kualitas barang dengan harga yang ditawarkan Menurut Dandi Setiyadi Putra (2018), "kalau menurut saya sendiri, harga dan kualitas barangnya sangat sesuai. Malahan harga yang diberikan tergolong cukup murah melihat kualitas barang dan melihat kalau ini karya tangan masyarakat bukan buatan mesin.Tapi kebanyakan pengrajin tidak memikirkan harga yang tinggi, mereka hanya berfikir lakunya barang, biarpun sedikit asalkan perputarannya cepat".

Hasil wawancara menjelaskan bahwa pembeli merasa kalau harga songko dengan kualitas barang yang diberikan ini sebenarnya tidak sebanding dengan usaha yang dilakukan oleh perajin, karena songko ini merupakan hasil kerajinan tangan manusia dan bukan hasil dari mesin.vKarena hasil kerajinan tangan 
Abdullah,: Regards; Istishna; Songko Recca.

harusnya harganya bisa lebih mahal, namun perajin juga memikirkan pembeli. Kalau perajin ingin mendapatkan keuntungan yang jauh lebih banyak, bisa membuat pembeli mereka pindah ke pembeli lainnya. Unsur keadilan, perajin sudah merasa adil, karena walaupun harga yang ditawarkan tergolong murah di mata pembeli, namun harga itu sudah sesuai dengan modal terlebih lagi perajin juga sudah memperoleh keuntungan. Keadilan berjualan di sini dapat disimpulkan bahwa dalam berjualan, kepuasan pembeli adalah hal paling utama, dengan memberikan harga yang sebanding dengan kualitas barang akan membuat pembeli merasa tidak terzholimi. Adanya sikap dari perajin, akan menjalin suatu konsep persaudaran terhadap pembeli dan Islam dengan tegas melarang seorang muslim merugikan orang lain (Rahim:2016:101)

Nilai kejujuran pada transaksi songko recca

\begin{tabular}{l|l}
\hline \multicolumn{1}{c|}{ Nilai Kejujuran } & \multicolumn{1}{c}{ Tujuan } \\
\hline $\begin{array}{l}\text { Menjelaskan Kualitas Bahan/ Jenis } \\
\text { Bahan }\end{array}$ & Untuk menentukan harga \\
\hline $\begin{array}{l}\text { Menjelaskan Jenis Songko' Yang Bermotif } \\
\text { Dengan Yang Tidak }\end{array}$ & $\begin{array}{l}\text { Untuk membedakan harga dan } \\
\text { kualitas }\end{array}$ \\
\hline Menjelaskan Waktu Penyelesaiannya & $\begin{array}{l}\text { Untuk menjaga kepercayaan } \\
\text { pembeli }\end{array}$ \\
\hline
\end{tabular}

Pandangan Islam, adil merupakan norma paling utama dalam seluruh aspek perekonomian (Qardhawi:2000). Ini berarti setiap transaksi yang terjadi harus dilakukan secara adil kepada semua pihak tanpa membedakan suku, bangsa, agama, jabatan, dan lain sebagainya. Peneliti melakukan wawancara kepada pengrajin mengenai harga yang diberikan, beliau mengatakan:

Menurut Darma (2018), "kalau masalah harga tentu ada pengurangan harga, tapi itupun kalau pembeli membeli songko lebih dari 1, dan itu berlaku untuk semua pembeli biarpun langganan. Tapi kalau mau lebih murah lebih bagus kalau beli lusinan. Karena akan lebih banyak potongan harganya".

Hasil wawancara peneliti dengan $\mathrm{Bu}$ Darma bahwa beliau tetap memberikan potongan harga kepada para pembeli baik itu yang sudah langganan maupun bagi pembeli baru. Pada pengurangan harga ini ada keadilan yang terjadi, karena tidak adanya perbedaan atau pilih kasih dari pengrajin terhadap langganannya dengan pembeli baru. Begitu pentingnya sifat adil ini sehingga Allah pun menjadikannya sebagai salah satu sifat-Nya. Ia menciptakan alam semesta (makrokosmos) ini dalam tatanan keadilan (Ar-Rahman:7), 
Manusia (mikrokosmos) juga diciptakan secara adil (Al-Infithar:7), dan menugaskan manusia sebagai khalifah juga untuk menegakkan keadilan di muka bumi (Shaad:26)

Pengrajin songko saudari Darni yang juga merupakan seorang mahasiswa IAIN Watampone. Beliau tetap bersikap baik kepada pembeli yang komplen karena masalah ketidaksesuaian pesanan dari pembeli.

Menurut Darniati Darwis (2018), “Pernah ada yang komplen karena ada motif yang tidak sesuai dengan pesanan, sehingga barang tadi dikembalikan ke saya untuk di perbaiki. Saya juga tidak memberikan tambahan harga untuk biaya perbaikan itu, karena saya tahu kalau itu merupakan kesalahan saya sendiri. Saya menjual songko untuk mendapatkan keuntungan, namun kalau pembeli merasa dizolimi, saya juga sebagai penjual merasa tidak enak".

Hasil wawancara tersebut bahwa perajin tetap dan bersedia untuk memperbaiki songko yang tidak sesuai dengan yang dipesan oleh pembeli. Sikap perajin yang bersedia memperbaiki songko itu tanpa meminta biaya tambahan akan adil bagi pembeli, karena pembeli sudah membayar songko tersebut dan berharap songko pesanannya dalam kondisi baik, namun nyatanya tidak. Sikap ini tanpa pengrajin sadari sudah memenuhi nilai-nilai Islam untuk tidak menzholimi pihak lain serta memperbaiki songko tersebut dengan niat yang tulus. Sebab niat yang tulus, semua bentuk aktivitas yang mubah (pekerjaan duniawi) berubah menjadi ibadah (Rahim:2016:99). Tidak hanya itu, dalam kegiatan transaksi ini, pengarajin secara tidak langsung telah memenuhi hak berupa pembayaran upah. Hasil wawancara peneliti dengan perajin bahwa nilai keadilan tidak hanya kepada pembeli, namun kepada perajin lain juga. Beliau mengatakan bahwa dalam proses pengerjaan ini tidak dilakukan oleh saya sendiri, tetapi saya di bantuoleh beberapa perajin. Sebenarnya Ibu Nani mampu menyelesaikan songkonya sendiri, namun itu akan membutuhkan waktu yang lebih lama lagi. Di samping itu ibu Nani telah membantu perajin lain dengan memberikan pekerjaan. Upah yang diberikan pun walaupun terlihat cukup murah, tapi bila songko yang dikerjakannya itu dalam jumlah banyak, pasti akan mendapatkan upah yang banyak pula. Meskipun keuntungan yang kecil per unit akan berdampak pada keuntungan yang lebih besar secara keseluruhan (Adesy:2016:105).

Nilai keadilan pada transaksi songko recca

\begin{tabular}{l|lll}
\hline \multicolumn{2}{c|}{ Nilai Keadilan } & \multicolumn{2}{c}{ Tujuan } \\
\hline $\begin{array}{l}\text { Menyamakan kualitas dan harga } \\
\text { barang }\end{array}$ & $\begin{array}{l}\text { Untuk meningkatkan } \\
\text { konsumen }\end{array}$ & kepuasan \\
\hline
\end{tabular}




\begin{tabular}{l|l} 
Pengurangan harga kesemua pembeli & Untuk menarik konsumen \\
\hline $\begin{array}{l}\text { Memperbaiki kesalahan tanpa biaya } \\
\text { tambahan }\end{array}$ & $\begin{array}{l}\text { Agar pembeli tetap menaruh } \\
\text { kepercayaan terhadap pengrajin }\end{array}$ \\
\hline $\begin{array}{l}\text { Menunaikan hak berupa pembayaran } \\
\text { upah }\end{array}$ & Agar perajin dapat memutar modalnya. \\
\hline
\end{tabular}

Seorang perajin yang bernama Siska menjelaskan omset yang diterimanya selama sebulan.

Menurut Siska (2018), "kalau masalah omset saya perbulan itu bisa sampai 10 juta rupiah untuk 1 kali penjualan, karena terkadang ada yang memesan songko dengan harga sampai jutaan rupiah, hal ini karena pembeli sudah mempercayai saya untuk membuatkan songko, bahkan pemasaran songko ini sekarang sudah sampai ke Negara Singapura"

Hasil dari wawancara tersebut menjelaskan bahwa kepercayaan yang dimulai dengan kejujuran akan memberikan sesuatu yang jauh lebih besar. Siska tidak akanpernah menduga bahwa songko buatannya ini bisa sampai ke Singapura. Pemasukan yang tergolong sangat lumayan ini merupakan suatu berkah dari Allah karena sikapnya yang jujur sehingga beliau dipercayakan kembali untuk membuat songko itu. Mungkin saja awalnya siska merupakan pengrajin kecil-kecilan, namun karena kepercayaan pembeli kepadanya sudah sangat besar, sehingga membuat banyak pembeli yang senang membeli songko padanya. Karena keberkahan itu bila ia berada pada sesuatu yang sedikit maka allah akan menjadikannya banyak dan bila sudah berapa pada sesuatu yang banyak, maka Allah akan menjadikannya bermanfaat, dan diantara buah keberkahan di dalam segala perkara adalah memanfaatkannya dalam ketaatan kepada Allah swt (Asyaqawy:2009). Penjelasan tersebut kita dapat menyimpulkan bahwa jual beli yang dimulai dengan yang baik, akan memberikan hasil yang baik pula, karena siapa yang menanam dia pulalah yang menuai hasilnya.

\section{Nilai Keberkahan}

\begin{tabular}{l|l}
\hline \multicolumn{1}{c|}{ Nilai keberkahan } & \multicolumn{1}{c}{ Tujuan } \\
\hline Perdagangan yang jujur & Untuk mendapatkan berkah dari Allah \\
\hline $\begin{array}{l}\text { Pemasaran sampai ke luar } \\
\text { daerah }\end{array}$ & $\begin{array}{l}\text { Agar masyarakat tahu bentuk kearifan } \\
\text { lokal bugis }\end{array}$ \\
\hline $\begin{array}{l}\text { Mulai dikenal di negara } \\
\text { tetangga }\end{array}$ & $\begin{array}{l}\text { Agar bisa menginternasionalkan songko } \\
\text { recca }\end{array}$ \\
\hline
\end{tabular}




\section{KESIMPULAN}

Terdapat beberapa nilai-nilai ekonomi Islam dalam transaksi akad salam dan akad istishna pada perajin songko recca (songko to Bone) Awangpone di Kabupaten Bone yaitu nilai keadilan, nilai kejujuran serta nilai keberkahan. Penerapan nilai-nilai ekonomi Islam dalam transaksi akad istishna dan Akad salam ini sebagian besar dari perajin telah menerapkan nilai-nilai ekonomi Islam ini. Hal ini ditunjukkan pada dimulai pada saat akad atau proses pemesanan dilakukan hingga proses barang selesai dan siap dikirimkan. Nilai keadilan serta nilai kejujuran yang diterapkan oleh sebagian besar perajin memberikan dampak positif bagi usaha mereka. Sikap jujur dan adilnya inilah yang memunculkan keberkahan disetiap usahanya sehingga usaha yang dijalani oleh perajin sering mendapat pesanan dari beberapa daerah bahkan sampai ke mancanegara. Selain itu akan memunculkan nilai tambah bagi perajin, baik itu nilai tambah material, mental maupun nilai tambah spiritual. 
Abdullah,: Regards; Istishna; Songko Recca.

\section{DAFTAR PUSTAKA}

Amalia, Euis. Keadilan Distributif Dalam Ekonomi Islam (Jakarta: Raja Grafindo Persada, 2009).

Annisa, Tsalis. 6 Macam Metode Analisis Data Yang Perlu Diketahui. Ekrut Media. 15 September 2020. https:/ / www.ekrut.com/media/macammacam-metode-analisis-data (17 oktober 2020)

Ascarya.Akad Dan Produk Bank Syariah. (cet. 5; Jakarta: rajawali press, 2015).

Astura, Andi. Pembeli Songko Recca (Songko to Bone) di Paccing Kab. Bone. Wawancara. 1 Agustus 2018.

Asyaqawy, Amin Abdullah. Keberkahan. (2009-1430)

Bahri, Syamsul. Pembeli Songko Recca (Songko to Bone) di Paccing Kab. Bone. Wawancara. 26 Juli 2018.

Darma. Pengrajin Songko Recca (Songko to Bone) di Paccing Kab. Bone. Wawancara. 26 Juli 2018.

Darwis, Darniati. (22 tahun). Pengrajin Songko Recca (Songko to Bone) di Paccing Kab. Bone. Wawancara. 26 Juli 2018.

Darwis, Lukman. Mengenal Songko To Bone.Kompasiana. 24 juni 2015.https:/ / www.kompasiana.com/ parentakoe/mengenal-songkok-tobone_54f7cb52a33311d41b8b4a80 (17maret 2018).

Dewan Pengurus Nasional Fordebi dan Adesy, Ekonomi dan Bisnis Islam: Seri Konsep Dan Aplikasi Ekonomi Dan Bisnis Islam. (Cet. I; Jakarta: rajawali, 2016).

Hesti. Pengrajin Songko Recca (Songko to Bone) di Paccing Kab. Bone. Wawancara. 28 Juli 2018.

Menurutpasal 1 angka 1 Undang-UndangNomor 20 tahun 2008 tentang UMKM (UU UMKM).

Putra, Dandi Setiyadi (23 tahun). Pembeli Songko Recca (Songko to Bone) di Paccing Kab. Bone. Wawancara. 1 Agustus 2018

Qardhawi, Yusuf. Nilai Dan Peran Moral Dalam Perekonomian Islam. (Jakarta: Robbani Press, 1997).

QS Al-Infithar:7. Al-Quran dan Terjemahya

QS Ar Rahman: 7. Al-Quran dan Terjemahya

QS Shaad:26. Al-Quran dan Terjemahnya

Rahim, Abdul. Nilai-Nilai Perekonomian Islam Dalam Ritual "Mappadendang". Jurnal Hukum Islam 14. no. 1 (2016).

Shihab, M. Quraish. Tafsir al-Mishbah. 
Siska. Pengrajin Songko Recca (Songko to Bone) di Paccing Kab. Bone. Wawancara. 26 Juli 2018.

Triyuwono, Iwan. "Mengangkat "Sing LIyan" untukFormulasi Nilai Tambah Syariah".JurnalAkuntansiMultiparadigma 2. no. 2 (2011).

Yunus, M. Ruslan.“Teknik Proses PemisahanSeratLontar”.LaporanHasil Penelitian (Makassar : Pelatihan Dalam Negeri Peningkatan Mutu dan Desain Kerajinan Anyaman Serat Lontar Kerja Sama Antara Balai Industri Ujung Pandang (BIUP) dengan Japan Internasional cooperation agency (JICA), 2000).

Yusuf, A. Muri.MetodePenelitianKuantitatif, KualitatifEPenelitianGabungan (Cet. I; Jakarta:Kencana, 2014).

Qardhawi, Yusuf. Norma Dan Etika Ekonomi Islam. (Jakarta:Gema InsanPress, 2000). 